\title{
The human imprint on the unique geological landscape of the Western Caucasus
}

\author{
Anna V. Mikhailenko ${ }^{1}$, Dmitry A. Ruban ${ }^{2,3 *}$, Svetlana O. Zorina ${ }^{4}$, \\ Konstantin I. Nikashin ${ }^{4}$, Natalia N. Yashalova ${ }^{5}$ \\ ${ }^{1}$ Institute of Earth Sciences, Southern Federal University, Zorge Street 40, Rostov-on-Don 344090, Russia \\ ${ }^{2}$ K.G. Razumovsky Moscow State University of Technologies and Management (The First Cossack University), \\ Zemlyanoy Val Street 73, Moscow 109004, Russia \\ ${ }^{3}$ Department of Hospitality Business, Higher School of Business, Southern Federal University, 23-ja Linija Street 43, \\ Rostov-on-Don 344019, Russia (postal address: P.O. Box 7333, Rostov-on-Don 344056, Russia) \\ ${ }^{4}$ Institute of Geology and Petroleum Technologies, Kazan Federal University, Kremlyovskaya Street 18, Kazan, \\ Republic of Tatarstan 420008, Russia \\ ${ }^{5}$ Department of Economics and Management, Business School, Cherepovets State University, Sovetskiy Avenue 10, \\ Cherepovets, Vologda Region 162600, Russia \\ *corresponding author; e-mail: ruban-d@mail.ru
}

\begin{abstract}
Human intervention in the geological environment is commonly thought to pose a threat to geoheritage. However, new information from the Western Caucasus where unique geological features are concentrated in Mountainous Adygeya, implies that man-made features in fact add value to geoheritage. Such features include a lengthy artificial niche in the Guama Gorge, accumulations of large artificial clasts along the road leading to the Lagonaki Highland and the Khadzhokh Quarry with the artificial Red Lake. These contribute to the regional uniqueness of geosites and can be classified as geomorphological, sedimentary, economical and hydro(geo)logical geoheritage types. Interestingly, these artificial features have natural analogues in the study area. Such integrity of local geological landscapes urgently require special interpretations for guided excursions and explanatory panels for correct comprehension of the origin of these unique features on the part of unprepared tourists. Generally, the human imprint on geological landscapes of Mountainous Adygeya is significant and occasionally positive, which makes the entire geodiversity hotspot of special, international interest and an object for further investigations.
\end{abstract}

Key words: artificial landform, geotourism, megaclast, quarry lake, southwest Russia

\section{Introduction}

In view of its global scale, the activity of humans is a geological force (Hooke, 2000; Wilkinson, 2005; Zalasiewicz et al., 2014; Cooper et al., 2018). The current geological epoch, although not yet accept- ed officially by the international stratigraphical research community, is referred to as the Anthropocene (Crutzen \& Stoermer, 2000; Zalasiewicz et al., 2008; Subramanian, 2019). Deep intervention of humans into the geological environment leads to both exposure of unique objects of natural origin and 
creation of new unique objects of artificial origin. Being a geological force, human activity does not only alter, but also co-creates geological landscape in conjunction with natural forces. Such artificial objects include man-made landforms, sedimentary strata, etc. A significant number of types and forms of geoheritage are linked to human activity (Ruban, 2020). With regard to these considerations, the geological activity of humans should not be considered only as a threat, but also as a complex mechanism of geoheritage transformation. Although these ideas appear easy to comprehend, they do need to be shaped and strengthened through the study of representative examples. An important research question addresses the change of geoheritage values thath uman alteration of geological landscapes entails.

The present study is the first attempt to characterise anthropogenic (i.e., artificially created) geoheritage from Mountainous Adygeya in the Western Caucasus - a geodiversity hotspot in southwestern Russia that is famous for its concentration of unique palaeogeographical (Late Jurassic reefs), geomorphological (peculiar canyons and gorges, as well as world-famous karst formations), palaeontological (ammonite and trace fossil localities) and other features (Ruban, 2010a). Here, human modifications of the geological environment have been ongoing since prehistory, and a significant increase of agricultural and mining activities took place in the second half of the twentieth century. Presently, this area is one of the most important destinations for Russian tourists, and the growth of touristic activities since the beginning of the twenty-first century has triggered significant changes linked to development of transport and recreation infrastructure, building and maintenance of tourist attractions. Importantly, the natural and, particularly, geological and geomorphological peculiarities (karst phenomena, waterfalls, unusual landforms, etc.) attract tourists. Generally, natural resources of this area can sustain both recreation and industrial development (Varshanina \& Matusov, 2006; Kiseleva et al., 2017).

Our field investigations in the Western Caucasus have permitted to find several geosites with a significant human imprint on the geological landscape, i.e., a natural landscape dominated by geological elements (Fig. 1). At these geosites, anthropogenic pressure has resulted in the creation of new elements of geoheritage. Moreover, man-made modifications of local geological landscapes have already attracted tourists to these geosites.

\section{Geological setting}

The study area is situated in the southwestern part of Russia where the Caucasian Mountains stretch between the Black Sea and the Caspian Sea (Fig. 1). Geographically, the area belongs to the Western Caucasus, which is the western domain of the Greater Caucasus. This area comprises the mountainous (southern) part of the Republic of Adygeya (a region of the Russian Federation) and adjacent parts of the Krasnodar Region. It corresponds to the basin of the River Belaya, which is a large left tributary of the River Kuban, which flows into the Azov Sea.

The Greater Caucasus (including its western domain) is the late Cenozoic (Alpine) orogen formed as a result of complex interactions between the Arabian Plate in the south, the Eurasian Plate in the north and several smaller blocks in between (Adamia et al., 2011b; Koulakov et al., 2012; Forte et al., 2014; Sharkov et al., 2015; Kaban et al., 2018; Van Hinsbergen et al., 2020; Ismail-Zadeh et al., 2020; Vasey et al., 2020). Its 'core' is the former Gondwana-derived terrane represented by Precambrian and Palaeozoic rocks (Ruban, 2013). The regional geolo-

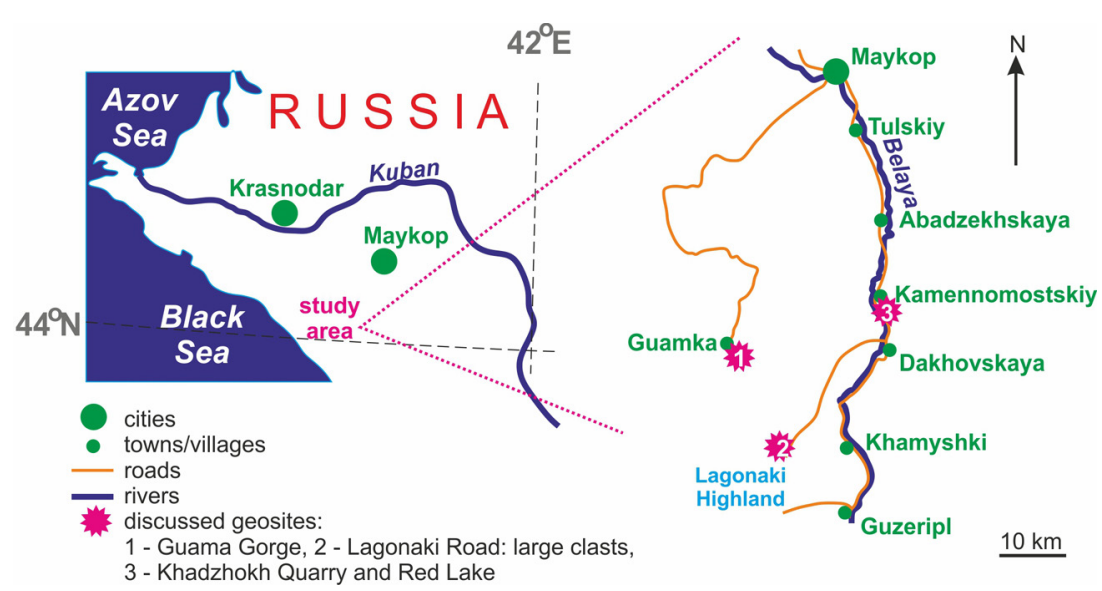

Fig. 1. Geographical location of the study area 
gy is dominated by Mesozoic-lower Cenozoic sedimentary complexes that formed in back-arc basins (Adamia et al., 2011a). The study area is located on the northern slope of the Greater Caucasus. The local geology was reviewed, particularly, by Lozovoj (1984), Rostovtsev et al. (1992) and Ruban (2010b). The oldest rocks are Precambrian metamorphic complexes and Palaeozoic serpentinites and granitoids that are exposed in small erosional 'windows'. The most widely distributed strata are Permian, red-colored molassic deposits (total thickness up to $10 \mathrm{~km}$ ), Lower-Middle Jurassic shales and sandstones (total thickness also up to $10 \mathrm{~km}$ ), Upper Jurassic carbonates and evaporites (total thickness about $3 \mathrm{~km}$ ) and Cretaceous mixed (siliciclastic-carbonate) packages (total thickness exceeding $1 \mathrm{~km}$ ). From south to north, these sedimentary complexes occur in successive 'belts'. The most notable geological phenomenon of the study area is the 'classical' karst development in the Lagonaki Highland where both epikarst (karren and karst depressions) and endokarst (caves and shafts) have been documented (Lozovoj, 1984; Veress et al., 2019).

Geodiversity hotspots are of primary importance in geoheritage studies despite certain differences in their definition (Gray, 2008; Ruban, 2010a; Stepišnik \& Repe, 2015; Bétard et al., 2018; Stepišnik \& Trenchovska, 2018; Bétard \& Peulvast, 2019; Manríquez et al., 2019). Generally, these are spatial concentrations of unique geological features that form geoheritage-dominated landscapes with scientific, educational and touristic importance and relevant aesthetic properties. Ruban (2010a) proposed Mountainous Adygeya as a geoheritage hotspot with several geosites ranking from local to global. The present studies have permitted us to consider a new geosite, namely the Guama Gorge (Fig. 1), which is known by its peculiar landforms, sedimentary rocks and fossils (Vorob'ev, 2014), and, thus, to extend the limits of the hotspot in a westerly direction.

\section{Methodology}

In the present study, we use the following terminology. This is provisional because terms used by modern researches are often very different, even contrasting (see also definitions in Habibi et al. (2018) and Williams et al. (2020)). Geosites are understood in broad terms and include those localities that represent the only unique geological phenomena and geomorphosites illustrating unique geomorphological phenomena. A geological landscape is a natural landscape that is dominated by geological (and geo- morphological) elements. A geodiversity hotspot is a large area that hosts geosites of diverse nature; its geological landscape is dominated by unique geological and geomorphological features. Human imprint on geoheritage can appear in different forms (Ruban, 2020). For instance, a distinction should be made between change (often damage) of geological objects or its natural/artificial exposure and creation of essentially artificial objects (e.g., man-made landform or man-made sediment accumulation). Nonetheless, such differences may be vague and/ or highly complex. Geoheritage types and forms are here understood sensu Habibi et al. (2018). Geoheritage types refer to unique phenomena - e.g., the sedimentary geoheritage type corresponds to unique sedimentary rocks or structures. Geoheritage forms refer to places where unique features are represented - e.g., natural outcrops, road cuttings, quarries, etc. In rare cases, geoheritage forms are unique themselves (e.g., due to their larger size that reflects human activity as a geological force); in the majority of cases, such unique forms should be attributed to the geomorphological type of geoheritage, to be described as geomorphosites.

Field investigations in Mountainous Adygeya and, particularly, our ongoing inventory of local geoheritage have enabled us to find three geosites that represent the human imprint on geological landscapes. These are the Guama Gorge in the western part of the study area, the large clast accumulations along the road skirting the northern periphery of the Lagonaki Highland, and the Khadzhokh Quarry with the Red Lake near the town of Kamennomostskiy (Fig. 1). Each of these geosites has been visited and described with special emphasis on the features representing the geological activity of humans.

Geoheritage types and forms available at each geosite were identified and valued. For this purpose, standardised types and forms were considered (see Ruban (2020), who updated the earlier classification of Habibi et al. (2018)). The geoheritage evaluation is based on establishing the uniqueness of the features. Uniqueness is a relative parameter that depends on the rarity of any given unique geological phenomenon on the scale of an area (local uniqueness), a region (regional uniqueness), a country (national uniqueness) or the world (global uniqueness) (Ruban, 2010a). Thus, anthropogenic imprint is characterised qualitatively. It appears to be important to consider the scale of anthropogenic imprint (local distribution), to demonstrate its contribution (if any) to the entire geoheritage value and to realise whether artificial features contrast with the local geological landscape. The last-named is- 
sue is necessary so as to understand whether human intervention into the geological environment affects the natural essence of local scenery, because this is an important parameter of visitor judgement (Kirillova et al., 2014). If the anthropogenic imprint makes the geological landscape look artificial or leads to a mix of natural and artificial features, this can be interpreted as a loss of the visual integrity of such a landscape.

Specific analyses were required in order to examine the sedimentary rocks of the Guama Gorge; these were sampled $\sim 1.5 \mathrm{~km}$ away from the northern entrance to the gorge. Microscope analysis of thin sections and X-ray powder diffraction (XRD) analysis were performed at Kazan Federal University (Kazan, Russia). Additionally, the relative abundance (percentage) of large clasts of different sizes was determined on a representative plot located near the entrance to Lagonaki Highland. For this purpose, we adopted the large clast nomenclature proposed by Bruno \& Ruban (2017).

\section{Results}

\subsection{Guama Gorge}

The Guama Gorge (Fig. 1) is a natural gorge formed by the River Kurdzhips that has cut a deep, narrow valley into indurated Upper Jurassic carbonates. The gorge has a length of $\sim 5 \mathrm{~km}$, while its width changes from $\sim 50$ to $<10 \mathrm{~m}$ and its depth reaches $400 \mathrm{~m}$. This impressive landform has a well-visible V-shaped profile (Fig. 2A). In the first half of the twentieth century, a railway was constructed along the entire gorge for some local transport solutions. Nowadays, this is used for touristic purposes, i.e., for train excursions along the gorge. For its construction, the morphology of the gorge was modified - steep slopes on the left bank of the river were cut to create a kind of lengthy 'shelf' for railway construction. In some places, it was impossible to cut slopes and niches ('half-tunnels') were constructed. One of such niches has a length of up to $250 \mathrm{~m}$, a height of 3-9 $\mathrm{m}$ and a width of up to 3 $\mathrm{m}$ (Fig. 2B). Interestingly, river erosion and intense karst development in carbonate rocks have resulted in the formation of natural cavities and niches on the right bank of the river (Fig. 2C). To unprepared visitors, it would be difficult to grasp the genetic difference between artificial and natural niches, as both look very 'natural'.

Sedimentary rocks cropping out along the slopes of the Guama Gorge are Upper Jurassic dolostones (Fig. 3A) with secondary calcite formations (Fig. 3B). Based on results of XRD analyses, dolomite content is as high as 99 per cent, that of calcite $\sim 1$ per cent. Thin sections demonstrated a significant degree of dolomite recrystallisation (Fig. 3C) and the presence of large grains of secondary calcite (Fig. 3D). The grains tend to occur in a manner of 'spots'; as a result, some portions of the rock are 'pure' dolostones, while others resemble dolomitised micritic limestones.

Three unique geological features are found in the Guama Gorge. First, there is the gorge itself, with its peculiar morphology (see above) that should be attributed to the geomorphological type of geoher-
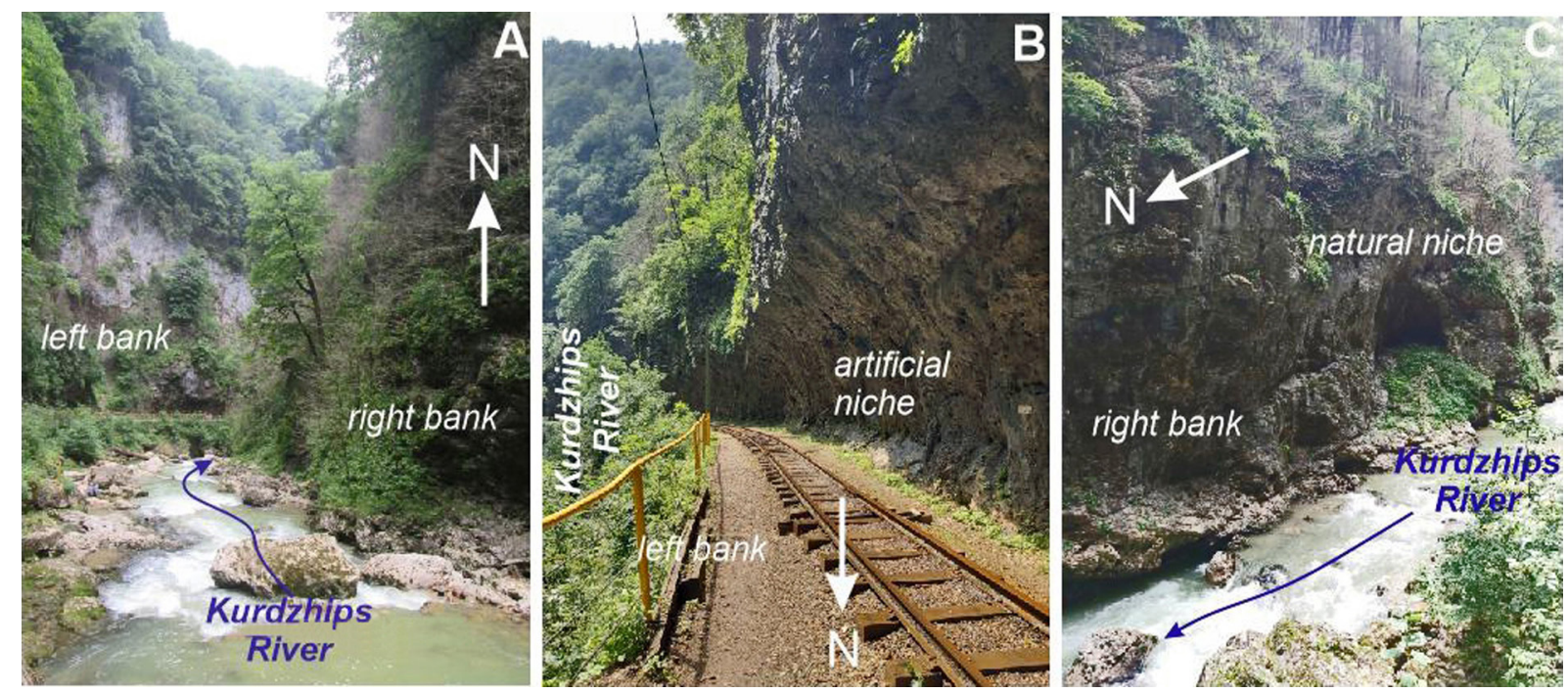

Fig. 2. Natural and artificial landforms of the Guama Gorge. A - General view of the gorge with outcrops of Upper Jurassic dolostones; B - Artificial niche along the left bank of the River Kurdzhipsr; C - Natural niche along the right bank of the River Kurdzhips. The north and the flow direction of the river are indicated 
Fig. 3. Upper Jurassic dolostones of the Guama Gorge. A - General view of a typical outcrop; B Secondary calcite formation; C General rock view in thin section (XPL); D - Secondary calcite in thin section (XPL)
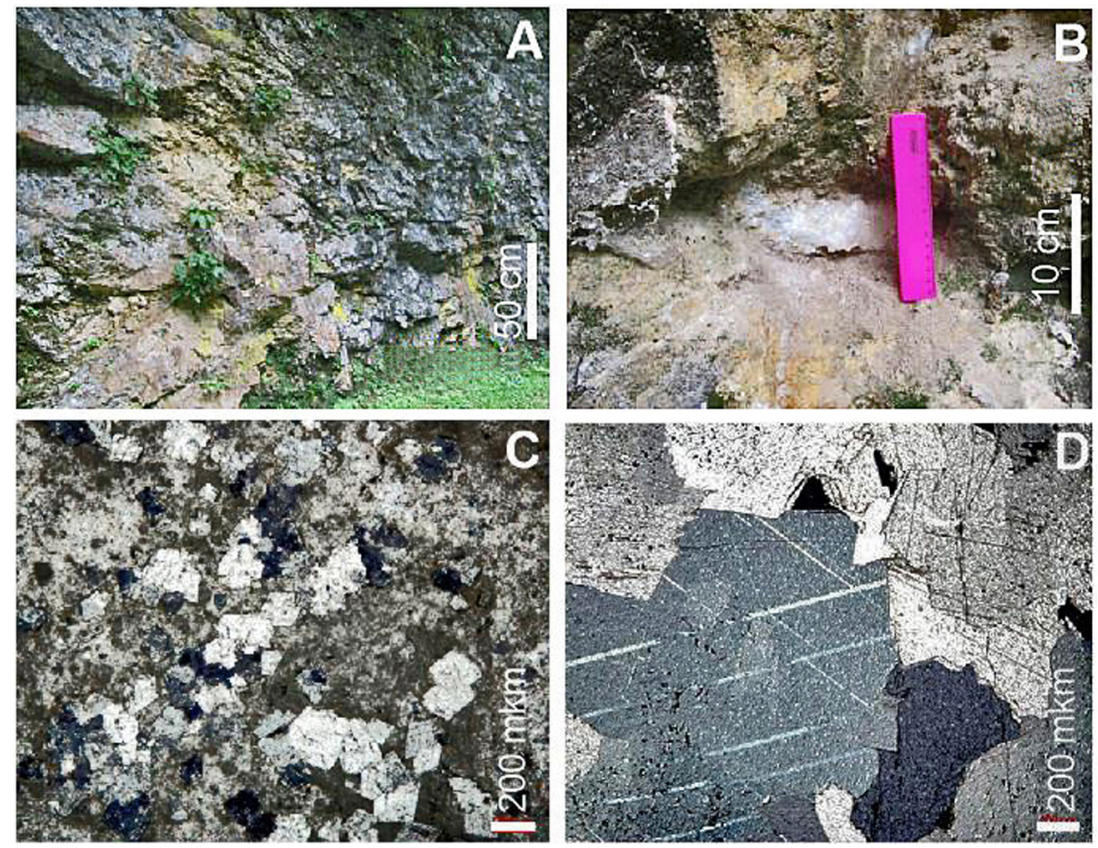

itage. The Guama Gorge is one of many landforms of this kind that are typical of the Western Caucasus (e.g., the Granite Gorge and Khadzhokh Canyon in the central part of the same geodiversity hotspot; see Ruban, 2010a). However, its geoheritage value is low and its uniqueness no more than local. But, artificial niches (Fig. 2B) are regionally unique features because of their unusual shape and size, and these represent geological and geomorphological activities of humans that are unprecedented on the scale of the entire Western Caucasus. These manmade forms lift the geomorphological uniqueness to a regional level. Secondly, the above-mentioned dolostones are notable. Similar rocks are distributed widely within Mountainous Adygeya (Lozovoj, 1984; Rostovtsev et al., 1992; Vorob'ev, 2014), and, thus, the uniqueness is local in this particular case. Thirdly, the Guama Gorge is a fossil locality where Tithonian bivalves, gastropods and fish teeth have been found (Vorob'ev, 2014). However, such finds are few, and there are comparable localities of the same kind in the Western Caucasus (Vorob'ev, 2014). Therefore, the uniqueness is also local in this case. The geoheritage form is highly specific in the Guama Gorge. On the one hand, this geosite is natural in regard to the origin of the gorge and numerous rock outcrops. On the other hand, there are artificial elements and the best dolostone outcrops are available in artificial niches and road cuttings.

The anthropogenic imprint on the geological landscape of the Guama Gorge is significant because the railroad stretches along the entire landform. As shown above, its presence affects the value of the geoheritage, raising it from local to regional.
Importantly, the anthropogenic geoheritage does not contrast with the natural geological landscape because the artificial elements resemble common natural elements (Fig. 2B, C). This means that the modification of the environment of the gorge has diversified this, rather than led to any loss of natural scenery. Importantly, the Guama Gorge combines natural and man-made geoheritage. The latter adds value to the site, but it cannot be said that geoheritage is essentially natural, although modified by human activity. In fact, the artificial niches, which determine the uniqueness of the entire site, are fully anthropogenic elements.

\subsection{Lagonaki road: large clasts}

This 32-km-long road connects Lagonaki Highland (a top regional tourist destination) with the main road between Maykop and Guzeripl (Fig. 1). Near the entrance to Lagonaki Highland, this road stretches along the toe of the Iron Plateau and then leads to the upper part of the cuesta-type Stonesea Range. Its construction in the 1970s and then episodic maintenance and widening required cutting hard, yet karstified Upper Jurassic carbonates (limestones and dolostones). As a result, artificial outcrops of these rocks were formed. These outcrops are of low importance due to excellent rock exposure in the vicinity, but voluminous removal of geological material resulted in the appearance of significant accumulations of large clasts along the road (Fig. $4 \mathrm{~A})$. These occur sporadically, but over a distance of $\sim 5 \mathrm{~km}$. These large clasts include boulders $(0.1-1 \mathrm{~m}$ 

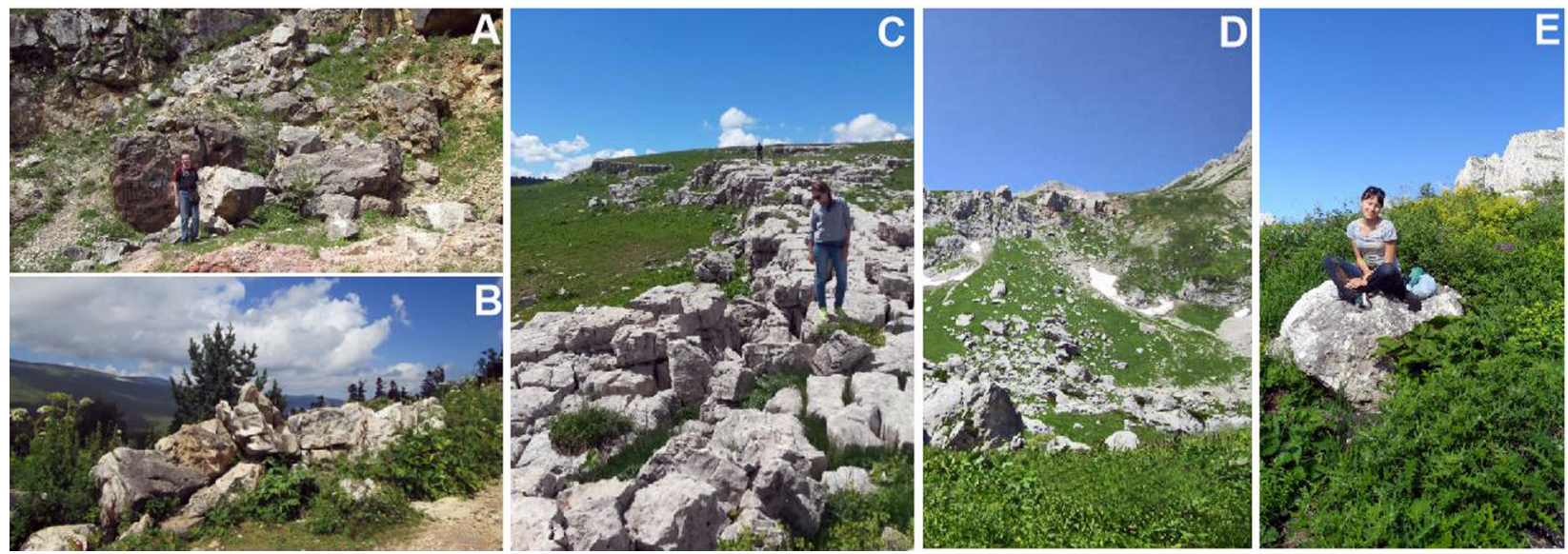

Fig. 4. 'Stones' of Lagonaki Highland. A - Local accumulation of large artificial clasts; B - Large artificial clasts along the road; C - Natural karren; D - Natural slope debris; E - Natural isolated megaclast. D.A.R. is for scale in A; A.V.M. in $\mathrm{C}$ and $\mathrm{E}$

in size) and typical megaclasts ( $>1 \mathrm{~m}$ in size) (sensu Bruno \& Ruban, 2017) (Fig. 5). In some places, these are replaced to mark the road borders (Fig. 4B).

Undoubtedly, large clasts accumulations form the sole unique geological feature of this geosite. Their regional uniqueness is determined by three reasons. First, these accumulations are rare on the scale of the Western Caucasus. Secondly, such accumulations are very important for studying megaclasts and testing different approaches to their classification (e.g., Blair \& McPherson, 1999; Blott \& Pye, 2012; Terry \& Goff, 2014; Bruno \& Ruban, 2017) and genetic models, which are important scientific tasks (Ruban et al., 2019). Thirdly, such accumulations are impressive with regard to the number of large clasts involved and their lengthy spatial distribution along the road. One can state the presence

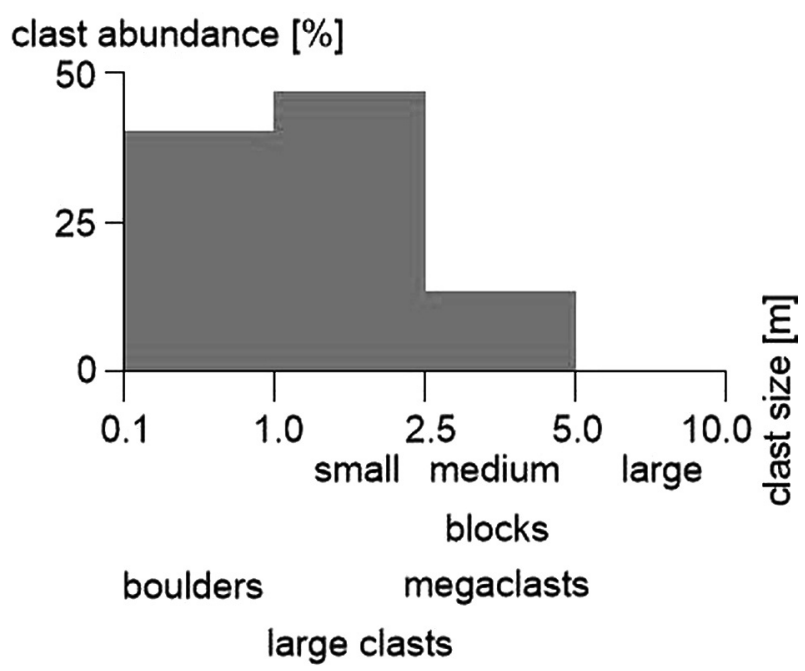

Fig. 5. Distribution of large clast sizes on the plot shown in Figure 4A. The large clasts are classified according to Bruno \& Ruban (2017) of a lenticular artificial deposit consisting of mixed boulders and megaclasts. This unique feature can be attributed to the sedimentary geoheritage type and the roadcut geoheritage form. Although some megaclasts are large objects that can be considered together with micro-landforms, these are essentially sedimentary particles that are considered in the professional literature only as such (Blair \& McPherson, 1999; Blott \& Pye, 2012; Terry \& Goff, 2014; Bruno \& Ruban, 2017; Ruban et al., 2019); these large clasts should not be confused with unique geomorphological features.

The human imprint on the geological landscape along the Lagonaki road is significant, as large clast accumulations dominate the scenery. Evidently, their very presence determines the value of this site, i.e., the latter would not be recognised as a geosite without these artificial elements. This anthropogenic geoheritage does not contrast with the natural geological landscape because of two reasons. First, large clasts consist of the same rocks that occur in natural outcrops along the Lagonaki road. Second$l y$, their accumulations resemble (especially in the eyes of unprepared visitors) natural carbonate outcrops with karren (Fig. 4C), slope debris (Fig. 4D) and isolated megaclasts (Fig. 4E). These natural features are very common in the Lagonaki Highland. Generally, this evidence means that the anthropogenic imprint does not affect the local scenery, but makes it more diverse.

\subsection{Khadzhokh Quarry and Red Lake}

A relatively large, abandoned quarry is located on the southern periphery of the town of Kamennomostskiy in the central part of Mountainous Ady- 
geya (Fig. 1). The quarry has a length of $\sim 500 \mathrm{~m}$, a width of $\sim 250 \mathrm{~m}$ and a depth of $\sim 50 \mathrm{~m}$. Limestones were quarried here for construction purposes during the twentieth century. The deepest part of the quarry is occupied by a small permanent lake (Fig. 6A) that formed as a result of accumulation of rainwater and groundwater, the latter flowing through carbonate packages. This lake, referred to as the Red Lake, is essentially artificial as it has appeared on the bottom of the quarry, but its formation is linked to natural forces. The lake is a very popular recreation attraction to the locals, and other visitors also appreciate it because of the picturesque scenery (Fig. 6B).

Several notable features are found in this geosite. These include the quarry itself, the Red Lake as a peculiar hydrological phenomenon, the Upper Jurassic limestones, the minor fossil localities (chiefly bivalves and brachiopods) in the quarry faces and numerous gypsum and calcite aggregates (including the so-called "gypsum roses" of white and pink colours) that may be interesting to mineral collectors. These correspond to the economical, hydro(geo)logical, sedimentary, palaeontological and mineralogical geoheritage types, respectively. The geomorphological type should be also established, as the abandoned quarry is an artificial landform. Almost all of these features are distributed widely even on a local scale, i.e., within the Republic of Adygeya. Therefore, their uniqueness is minimal (local), if any. Naturally, the geoheritage form is a quarry. The Red Lake is of greater uniqueness and its presence contributes to the higher rank of the entire geosite. For this, there are three arguments, as follows. First, this appears to be the only lake of this kind in the region. Secondly, this lake permits investigation of human-triggered hydrological phenomena. Thirdly, the lake adds significant attractiveness to the local geological landscape. As a result, the uniqueness of this hydrological feature is regional.

The entire Khadzhokh Quarry represents a significant anthropogenic imprint on the geological landscape, as this feature dominates the southern vicinities of Kamennomostkiy. The very presence of the quarry, with the artificial lake, determines the existence of the geosite. Moreover, the local geological landscape would be significantly less diverse and the number of geological elements lower. This anthropogenic geoheritage contrasts with the natural landscape, but not so strongly. First, the quarry faces of outcropping Upper Jurassic carbonates resemble natural outcrops of the same rocks in the Khadzhokh Canyon that stretches just to the south of this geosite. Secondly, being an artificial feature, the Red Lake makes the quarry look more natural, as it resembles typical mountain lakes distributed over Lagonaki Highland (Fig. 6C) and occurring within similar geological contexts (i.e., in domains dominated by Jurassic sedimentary rocks).
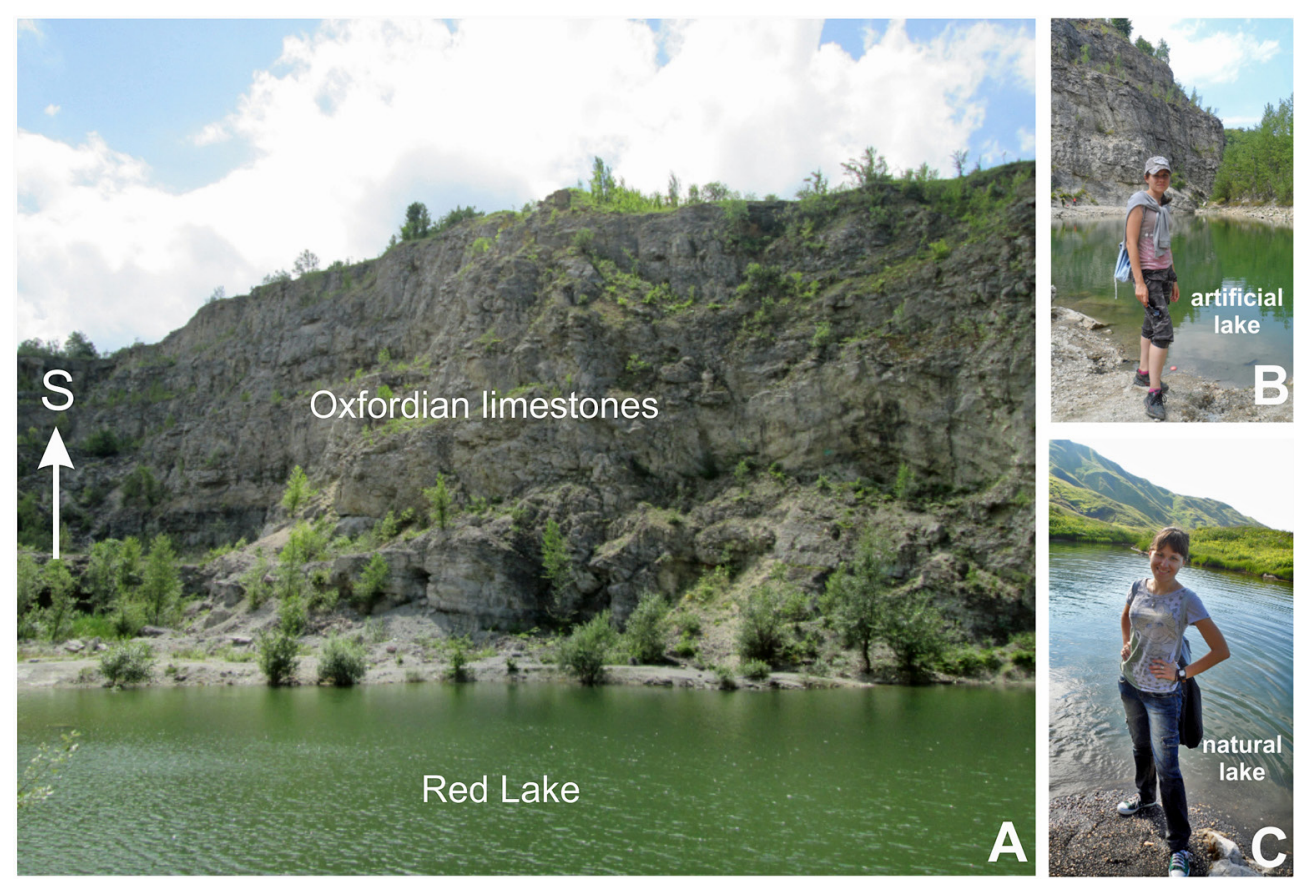

Fig. 6. Lakes in the geodiversity hotspot. A - Southern flank of Khadzhokh Quarry and the Red Lake; B - Western flank of Khadzhokh Quarry and the Red Lake; C - A natural lake nearby on Lagonaki Highland. The south is indicated. A.V.M. constitutes the scale in B and C 


\section{Discussion}

\subsection{Summary of local findings}

The three examples of significant anthropogenic imprint on local geological landscapes in the Mountainous Adygeya geodiversity hotspot allow some important interpretations to be made. First of all, man-made geoheritage is recognised at each geosite discussed, and is assigned to standard geoheritage types and forms (Ruban, 2020). The unique artificial features correspond to different types, namely geomorphological, sedimentary and economic and hydro(geo)logical types, i.e., the anthropogenic geoheritage is heterogeneous in this geodiversity hotspot. In the case of the Lagonaki road and Khadzhokh Quarry, the human imprint determines the very existence of these geosites. In the case of the Guama Gorge, it increases the heritage value of the geological landscape. In all cases, the anthropogenic features do not contrast (at least, not strongly) with the natural landscapes because these features resemble natural features that are common in the geodiversity hotspot. This is evidence of visual integrity of artificial and natural components in the geological landscapes studied.

With regard to the above, it is possible to infer that the anthropogenic imprint discussed contributes to the geoheritage value, despite significant modification of local geological landscapes. Two additional notes are necessary. First, anthropogenic imprint can also lead to some geoheritage loss. For instance, this would occur if railway construction in the Guama Gorge had resulted in the full destruction of this unique landform or if the Khadzhokh Quarry had obliterated an important fossil locality. The absence of such at the three geosites of the Mountainous Adygeya geodiversity hotspot is just an occasion, not a rule. Secondly, recognition of geoheritage itself leads to human pressure on the geological environment, especially when this geoheritage is exploited for the purposes of (geo)tourism. This can occur in the form of excess collecting of fossils, damage to outcrops due to infrastructure development, etc. However, evidence from Mountainous Adygeya demonstrates that even the very significant human intervention in the geological environment can have a positive effect on geoheritage values.

Generally, the anthropogenic factor in geoheritage can be conceptualised in terms of transformations and highly complex influence of human activity (Fig. 7). The human imprint on the geological landscape changes its value, and these changes can be both positive (generation of new values) and neg-

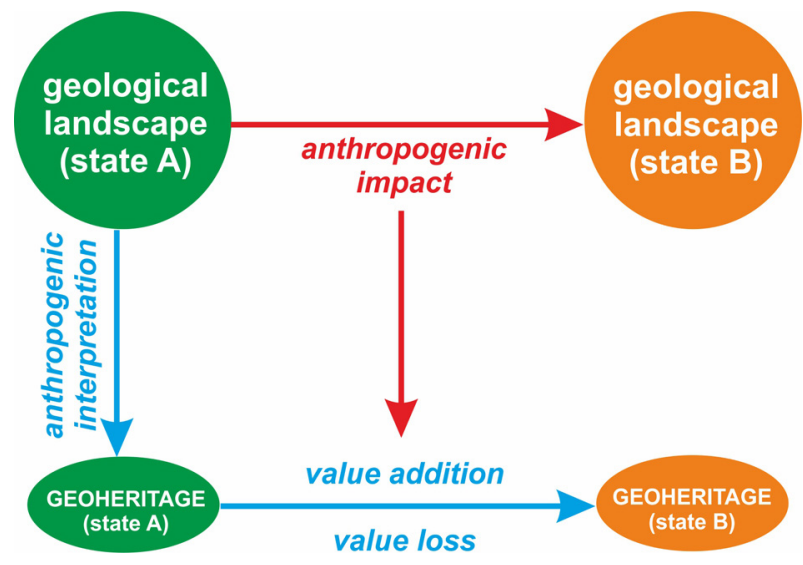

Fig. 7. Various types of human imprint on geological landscapes of the study area

ative (geoheritage loss). This means that geoheritage and geodiversity do not only appeal to cultural values and provide material and information for cultural development (Gordon, 2018), but also evolve into something new under human influence. Moreover, the examples from the study area demonstrate that anthropogenic geoheritage features are able to facilitate the merger of natural and cultural phenomena. For instance, the high aesthetic properties of the Guama Gorge are closely linked to both the natural process of a river cutting into hard rocks and artificial niche construction, and these features seem to be indistinguishable visually. Thus, the local geological heritage is enriched by human intervention. Taha et al. (2020) described another interesting example of how the activities of ancient civilisations changed the local geological landscape and contributed to its higher value, but modern development of that area led to increased risks of value loss.

Conceptually, geoheritage is the result of interpretation of geological landscape (Fig. 7). However, its value depends on its physical, objective state and, thus, any changes in this state lead to geoheritage transformations that are only in part dependent on interpretations. This means that the interpretations should be really correct and always address changes and transformations noted. In other words, geoheritage assessment should avoid focusing on natural objects alone.

\subsection{Limitations, perspectives, and implications}

The main limitation of the present study is linked to the restricted uniqueness of the geosites discussed and their anthropogenic elements. Their heritage value is no more than regional, and these geosites are of a relatively small scale. However, this limita- 
tion is unimportant in the present study because of two reasons. First, the geosites demonstrate amply how the human imprint on geological landscapes can contribute to geoheritage value in principle. Secondly, the purpose of the present study is to report the very presence of anthropogenic geoheritage in Mountainous Adygeya, irrespective of whether this geoheritage is of global or regional importance.

The present research findings open wide perspectives for geoheritage exploration and interpretation in the study area. The preliminary inventory of already known geosites allows documentation of human imprint on these (Fig. 8). Apparently, most numerous are cases in which this imprint is significant and direct, but related to geoheritage exploitation in tourism. For instance, this is the case of the Colonel Valley to the south of the village of Abadzekhskaya. This famous locality of Aptian ammonites (Vorob'ev, 2014) permanently loses heritage value due to excess collecting by amateurs who can be classed as geotourists. Another example is Lagonaki Highland where infrastructural development for ecotourism has resulted in significant geological landscape modification, and the heritage loss in this case is linked particularly to negative changes in the natural scenery. In one place, indirect human imprint is established. Forest clearing and engineering solutions along the scenic road leading from the town of Guzeripl to the Partisan Glade in the south of the geodiversity hotspot (Fig. 8) trigger mass wasting with numerous landslides and rockfalls, which damage natural and road cuttings of the Lower-Middle Jurassic shales. However, the anthropogenic imprint on geological landscapes resulting in heritage value creation is also documented in Mountainous Adygeya. In addition to the three geosites characterised in the present study, this creative imprint is found in two other places, namely on the Partisan Glade

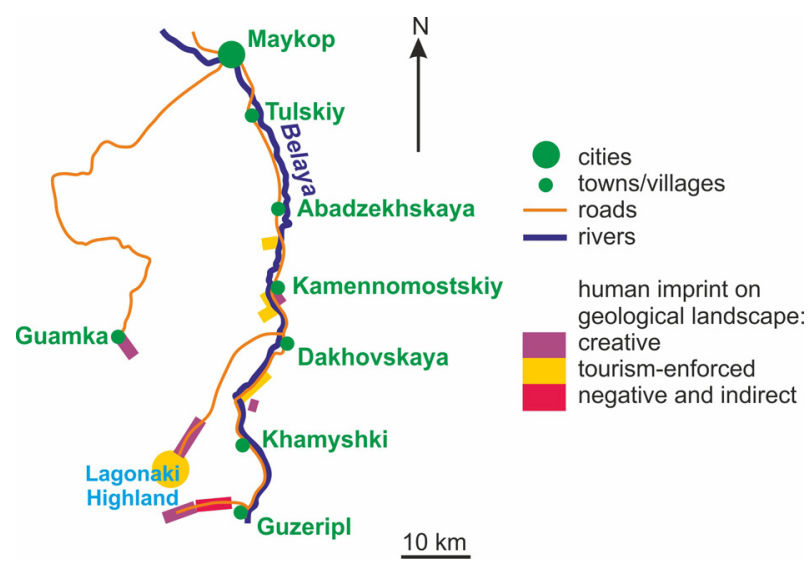

Fig. 8. Schematic representation of interaction between geological landscape, geoheritage and human activity in the study area where an artificial lake is constructed and on the southern flank of the Dakh Crystalline Massif where a new quarry provides exceptional opportunities for studying Upper Palaeozoic granitoids; both sites are in need of special investigations. All this evidence implies that the study area offers various opportunities for further investigations of anthropogenic geoheritage, and Mountainous Adygeya deserves the attention from the international research community involved in the geoheritage studies.

The results of the present study have two principal implications. First, positive effects of human imprint on geological landscapes increase the value of the entire Mountainous Adygeya geodiversity hotspot, as these effects themselves are unique. The geoheritage of this hotspot requires approaches of conservation and promotion that take into account the significance of geological activity of humans. Particularly, the reported man-made features should be conserved with the same responsibility as would typically natural features (protection from any natural damage or modification due to further infrastructure development), and the former need to be addressed in local geotourism initiatives. Secondly, the visual similarity of natural and artificial objects, as well as the mix of natural and anthropogenic phenomena in the same geosite, have been revealed. Particularly, artificial and natural niches of the Guama Gorge (Fig. 2B, C), artificial and natural megaclasts of Lagonaki Highland (Fig. 4A-E) and artificial and natural lakes of the hotspot (Fig. $6 \mathrm{~B}, \mathrm{C})$ look closely similar, as well as the geological landscapes in which these occur. On the one hand, this permits to diversify the content of geotouristic excursions avoiding focusing on only natural features. On the other hand, such a similarity makes geoheoritage interpretation to geotourists more challenging. Interpretation procedures are vital in effective communication of geoheritage-related knowledge to (geo)tourists, as well as to locals and policy-makers (Reynard, 2008; Moreira, 2012; Newsome et al., 2012; Martin, 2014; You et al., 2014; Began et al., 2017; Migoń \& Pijet-Migoń, 2017; Modrej et al., 2018; Bruno \& Wallace, 2019; Migoń et al., 2019). The majority of these do not have a sufficient command of professional knowledge to a correct understanding of geological features and their origin. The visual similarity of artificial and natural features requires to draw special attention to their origin and differences in the course of guided excursions or on explanatory panels. The latter were installed a few years ago along the principal tourist trails on Lagonaki Highland and the Rufabgo Waterfalls, although these provide chiefly ecological information. This experience can be taken into 
account at other major geosites; first and foremost, the Guama Gorge which attracts crowds of tourists. Undoubtedly, professionals in geology should be involved for clarity of explanations and clear distinctions between features of different origin.

\section{Conclusions}

The present research describes the fairly rather diverse, man-made geoheritage at three geosites in the Mountainous Adygeya geodiversity hotspot of southwestern Russia and allows to draw some general conclusions. First, human imprint on the geological landscapes of these sites is significant and positive, i.e., it adds or even creates heritage value. Secondly, the anthropogenic geoheritage is assigned to different geoheritage types, which indicates its local heterogeneity. Thirdly, all artificial features recorded have natural analogues in the same hotspot, and this co-occurrence contributes to the value of the latter, although is challenging to geoheritage interpretation by tourists.

These findings are indicative of the urgency of consideration of human imprint on geological landscapes as something more than just geoheritage disturbance (compare Petersen, 2002; Lóczy, 2010; Reynard \& Brilha, 2018; Kubalíková et al., 2019; Prosser, 2019). In some cases, this imprint can augment the uniqueness and attractiveness of the territory. This is especially important for geodiversity hotspots that are ideal for the creation of geoparks and the relevant questions should be addressed in future research.

\section{Acknowledgements}

The authors thank the journal editor and two anonymous reviewers for their helpful suggestions. The contribution by S.O.Z. and K.I.N. is performed according to the Russian Government program of competitive growth of Kazan Federal University and is supported by the Ministry of Science and High Education of the Russian Federation contract No. 14.Y26.31.0029 in the framework of the Resolution No.220 of the Government of the Russian Federation. The research contributions by A.V.M., D.A.R. and N.N.Y. were not funded.

\section{References}

Adamia, S., Alania, V., Chabukiani, A., Kutelia, Z. \& Sadradze, N., 2011a. Great Caucasus (Cavcasioni): A
Long-lived North-Tethyan Back-Arc Basin. Turkish Journal of Earth Sciences 20, 611-628.

Adamia, S., Zakariadze, G., Chkhotua, T., Sadradze, N., Tsereteli, N., Chabukiani, A. \& Gventsadze, A., 2011b. Geology of the Caucasus: A review. Turkish Journal of Earth Sciences 20, 489-544.

Began, M., Višnic, T., Djokic, M. \& Vasiljevic, D.A., 2017. Interpretation Possibilities of Geoheritage in Southeastern Serbia-Gorge and Canyon Study. Geoheritage 9, 237-249.

Bétard, F. \& Peulvast, J.-P., 2019. Geodiversity Hotspots: Concept, Method and Cartographic Application for Geoconservation Purposes at a Regional Scale. Environmental Management 63, 822-834.

Bétard, F., Peulvast, J.-P., Magalhães, A.O., Carvalho Neta, M.L. \& de Freitas, F.I., 2018. Araripe Basin: A Major Geodiversity Hotspot in Brazil. Geoheritage 10, 543-558.

Blair, T.C. \& McPherson, J.G., 1999. Grain-size and textural classification of coarse sedimentary particles. Journal of Sedimentary Research 69, 6-19.

Blott, S.J. \& Pye, K., 2012. Particle size scales and classification of sediment types based on particle size distributions: Review and recommended procedures. Sedimentology 59, 2071-2096.

Bruno, B.C. \& Wallace, A., 2019. Interpretive Panels for Geoheritage Sites: Guidelines for Design and Evaluation. Geoheritage 11, 1315-1323.

Bruno, D.E. \& Ruban, D.A., 2017. Something more than boulders: A geological comment on the nomenclature of megaclasts on extraterrestrial bodies. Planetary and Space Science 135, 37-42.

Cooper, A.H., Brown, T.J., Price, S.J., Ford, J.R. \& Waters, C.N., 2018. Humans are the most significant global geomorphological driving force of the 21st century. Anthropocene Review 5, 222-229.

Crutzen, P.J. \& Stoermer, E.F., 2000. The "Anthropocene". Global Change Newsletter 41, 17.

Forte, A.M., Cowgill, E. \& Whipple, K.X., 2014. Transition from a singly vergent to doubly vergent wedge in a young orogen: The Greater Caucasus. Tectonics 33, 2077-2101.

Gordon, J.E., 2018. Geoheritage, Geotourism and the Cultural Landscape: Enhancing the Visitor Experience and Promoting Geoconservation. Geosciences 8, 136.

Gray, M., 2008. Geodiversity: developing the paradigm. Proceedings of the Geologists' Association 119, 287-298.

Habibi, T., Ponedelnik, A.A., Yashalova, N.N. \& Ruban, D.A., 2018. Urban geoheritage complexity: Evidence of a unique natural resource from Shiraz city in Iran. Resources Policy 59, 85-94.

Hooke, R.LeB., 2000. On the history of humans as geomorphic agents. Geology 28, 843-846.

Ismail-Zadeh, A., Adamia, S., Chabukiani, A., Chelidze, T., Cloetingh, S., Floyd, M., Gorshkov, A., Gvishiani, A., Ismail-Zadeh, T., Kaban, M.K., Kadirov, F., Karapetyan, J., Kangarli, T., Kiria, J., Koulakov, I., Mosar, J., Mumladze, T., Müller, B., Sadradze, N., Safarov, R., Schilling, F. \& Soloviev, A., 2020. Geodynamics, seismicity, and seismic hazards of the Caucasus. Earth-Science Reviews 207, 103222. 
Kaban, M.K., Petrunin, A.G., El Khrepy, S. \& Al-Arifi, N., 2018. Diverse Continental Subduction Scenarios Along the Arabia-Eurasia Collision Zone. Geophysical Research Letters 45, 6898-6906.

Kirillova, K., Fu, X., Lehto, X. \& Cai, L., 2014. What makes a destination beautiful? Dimensions of tourist aesthetic judgment. Tourism Management 42, 282-293.

Kiseleva, S.V., Korinevich, L.A. \& Lebedev, S.A., 2017. Assessment of the renewable energy potential in the Republic of Adygeya. Ecologica Montenegrina 14, 143151.

Koulakov, I., Zabelina, I., Amanatashvili, I. \& Meskhia, V., 2012. Nature of orogenesis and volcanism in the Caucasus region based on results of regional tomography. Solid Earth 3, 327-337.

Kubalikova, L., Kirchner, K., Kuda, F. \& Machar, I., 2019. The role of anthropogenic landforms in sustainable landscape management. Sustainability 11, 4331.

Lóczy, D., 2010. Anthropogenic geomorphology in environmental management. In: Szabó, J., Dávid, L. \& Lóczy, D. (Eds): Anthropogenic Geomorphology: A Guide to Man-Made Landforms. Springer, Dordrecht, pp. 2538.

Lozovoj, S.P., 1984. Lagonakskoe nagor'e (Lagonaki Highland). Krasnodar (Krasnodarskoe Knizhnoe Izdatel'stvo), 160 pp. (in Russian)

Manríquez, H., Mansilla, P., Figueroa-Sterquel, R. \& Moreira-Muñoz, A., 2019. Geodiversity meets Biodiversity: A landscape approach for biogeocultural conservation and governance in Mediterranean central Chile. Eco.mont 11, 43-48.

Martin, S., 2014. Interactive visual media for geomorphological heritage interpretation. Theoretical approach and examples. Geoheritage 6, 149-157.

Migoń, P. \& Pijet-Migoń, E., 2017. Interpreting geoheritage at New Zealand's geothermal tourist sites - Systematic explanation versus storytelling. Geoheritage 9, 83-95.

Migoń, P., Duszyński, F., Jancewicz, K. \& Różycka, M., 2019. From Plateau to Plain - using space-for-time substitution in geoheritage interpretation, Elbsandsteingebirge, Germany. Geoheritage 11, 839-853.

Modrej, D., Fajmut Štrucl, S. \& Hartmann, G., 2018. Results of the geointerpretation research in the frame of the Danube GeoTour project. Geologija 61, 101-110.

Moreira, J.C., 2012. Interpretative panels about the geological heritage - a case study at the Iguassu Falls National Park (Brazil). Geoheritage 4, 127-137.

Newsome, D., Dowling, R. \& Leung, Y.-F., 2012. The nature and management of geotourism: A case study of two established iconic geotourism destinations. Tourism Management Perspectives 2-3, 19-27.

Petersen, J.F., 2002. The role of roadcuts, quarries, and other artificial exposures in geomorphology education. Geomorphology 47, 289-300.

Prosser, C.D., 2019. Communities, quarries and geoheritage - making the connections. Geoheritage 11, 12771289.

Reynard, E., 2008. Scientific research and tourist promotion of geomorphological heritage. Geografia Fisica e Dinamica Quaternaria 31, 225-230.
Reynard, E. \& Brilha, J. (Eds), 2018. Geoheritage: Assessment, Protection, and Management. Elsevier, Amsterdam, $482 \mathrm{pp}$.

Rostovtsev, K.O., Agaev, V.B., Azarian, N.R., Babaev, R.G., Besnosov, N.V., Hassanov, N.A., Zesashvili, V.I., Lomize, M.G., Paitschadze, T.A., Panov, D.I., Prosorovskaya, E.L., Sakharov, A.S., Thodria, V.A., Topchishvili, M.V., Abdulkasumzade, M.R., Avanesian, A.S., Belenkova, V.S., Bendukidze, N.S., Vuks, V.Ya., Doludenko, M.P., Kiritchkova, A.I., Klikushin, V.G., Krimholz, G.Ya., Romanovskaya, G.M. \& Schevchenko, T.V., 1992. Yura Kavkaza (Jurassic of the Caucasus). Nauka, St. Petersburg, 192 pp. (in Russian)

Ruban, D.A., 2010a. Quantification of geodiversity and its loss. Proceedings of the Geologists' Association 121, 326-333.

Ruban, D.A., 2010b. The Permian/Triassic mass extinction among brachiopods in the Northern Caucasus (northern Palaeo-Tethys): A tentative assessment. Geobios 43, 355-363.

Ruban, D.A., 2013. The Greater Caucasus - A Galatian or Hanseatic terrane? Comment on "The formation of Pangea" by G.M. Stampfli, C. Hochard, C. Vérard, C. Wilhem and J. von Raumer [Tectonophysics 593 (2013) 1-19]. Tectonophysics 608, 1442-1444.

Ruban, D.A., 2020. Geological heritage of the Anthropocene Epoch - a conceptual viewpoint. Heritage 3, 19-28.

Ruban, D.A., Ponedelnik, A.A. \& Yashalova, N.N., 2019. Megaclasts: term, use and relevant biases. Geosciences 9, 14 .

Sharkov, E., Lebedev, V., Chugaev, A., Zabarinskaya, L., Rodnikov, A., Sergeeva, N. \& Safonova, I., 2015. The Caucasian-Arabian segment of the Alpine-Himalayan collisional belt: Geology, volcanism and neotectonics. Geoscience Frontiers 6, 513-522.

Stepišnik, U. \& Repe, B., 2015. Identification of geodiversity hotspots on example of the Rakov Škocjan landscape park. Dela 44, 45-62.

Stepišnik, U. \& Trenchovska, A., 2018. A new quantitative model for comprehensive geodiversity evaluation: the Škocjan Caves Regional Park, Slovenia. Geoheritage 10, 39-48.

Subramanian, M., 2019. Humans versus Earth: the quest to define the Anthropocene. Nature 572, 168-170.

Taha, M.M.N., Al-Hashim, M.H. \& El-Asmar, H.M., 2020. Geoarcheomorphosites under strong urbanization pressure at the Tineh Plain, NE of the Nile Delta, Egypt. Geoheritage 12, 24.

Terry, J.P. \& Goff, J., 2014. Megaclasts: proposed revised nomenclature at the coarse end of the Udden-Wentworth gain-size scale for sedimentary particles. Journal of Sedimentary Research 84, 192-197.

Van Hinsbergen, D.J.J., Torsvik, T.H., Schmid, S.M., Matenco, L.C., Maffione, M., Vissers, R.L.M., Gürer, D. \& Spakman, W., 2020. Orogenic architecture of the Mediterranean region and kinematic reconstruction of its tectonic evolution since the Triassic. Gondwana Research 81, 79-229.

Varshanina, T.P. \& Matusov, D.V., 2006. Bioclimatic regionalization of Adygeya. Izvestiya Akademii Nauk, Seriya Geograficheskaya 4, 115-121. 
Vasey, D., Cowgill, E., Roeske, S.M., Niemi, N.A., Godoladze, T., Skhirtladze, I. \& Gogoladze, S., 2020. Evolution of the Greater Caucasus basement and formation of the Main Caucasus Thrust, Georgia. Tectonics 39, e2019TC005828.

Veress, M., Telbisz, T., Toth, G., Loczy, D., Ruban, D.A. \& Gutak, J.M., 2019. Glaciokarsts. Springer, Cham, 516 pp.

Vorob'ev, I.E., 2014. Poisk iskopaemykh na Severo-Zapadnom Kavkaze. Krasnodarskij kraj i Respublika Adygeja (Fossil search on the North-Western Caucasus. Krasnodar Region and Republic of Adygeya). KO RosGeo, Krasnodar, 300 pp.

Wilkinson, B.H., 2005. Humans as geologic agents: A deep-time perspective. Geology 33, 161-164.

Williams, M.A., McHenry, M.Y. \& Boothroyd, A., 2020. Geoconservation and geotourism: Challenges and unifying themes. Geoheritage 12, 63.
You, Y., Tian, M., Yang, Y. \& Gao, L., 2014. Construction of geoparks' interpretation system based on geoheritage protection. WIT Transactions on Ecology and the Environment 189, 863-870.

Zalasiewicz, J., Waters, C.N. \& Williams, M., 2014. Human bioturbation, and the subterranean landscape of the Anthropocene. Anthropocene 6, 3-9.

Zalasiewicz, J., Williams, M., Smith, A., Barry, T.L., Coe, A.L., Bown, P.R., Brenchley, P., Cantrill, D., Gale, A., Gibbard, P., Gregory, F.J., Hounslow, M.W., Kerr, A.C., Pearson, P., Knox, R., Powell, J., Waters, C., Marshall, J., Oates, M., Rawson, P. \& Stone, P., 2008. Are We Living in the Anthropocene? GSA Today 18, 4-8.

Manuscript received: 20 April 2020 Revision accepted: 2 September 2020 